\title{
HUBUNGAN PERILAKU KEIKUTSERTAAN KELAS IBU HAMIL DENGAN TINGKAT KECEMASAN DALAM MENGHADAPI PERSALINAN PADA IBU HAMIL PRIMIGRAVIDA TRIMESTER III
}

\section{DESA KALISAPU KECAMATAN SLAWI}

\author{
Adrestia Rifki Naharani ${ }^{1}$, Siswati ${ }^{2}$, Natiqotul Fatkhiyah ${ }^{3}$ \\ email: afzaa.luve@gmail.com \\ ${ }^{1,2,3}$ Program Studi D-3 Kebidanan STIKes Bhakti Mandala Husada Slawi \\ Tlp. 082322195050
}

\begin{abstract}
Abstrak
Kelas Ibu hamil adalah sarana untuk belajar tentang kesehatan ibu hamil, dengan tatap muka berkelompok yang bertujuan untuk meningkatkan pengetahuan dan keterampilan ibu-ibu mengenai kehamilan, persalinan, nifas dan bayi baru lahir. Faktor yang mempengaruhi keikutsertaan ibu hamil untuk mengikuti kelas ibu hamil adalah faktor karakteristik (umur, pendidikan, pekerjaan, paritas), faktor predisposisi (pengetahuan, sikap, minat, sosial budaya), faktor pendukung (sarana pelayanan kesehatan), faktor pendorong (dukungan keluarga, motivasi, petugas kesehatan dan sosial ekonomi). Jenis penelitian korelasional dengan pendekatan secara cross sectional. Populasi penelitian ini adalah seluruh ibu hamil TM III di Desa Kalisapu pada bulan Maret-April tahun 2017. Sampelnya sebanyak 30 orang. Pengolahan data dengan aplikasi SPSS versi 16. Uji statistik bivariat dengan Spearman Rank $(\alpha=0,05)$. Hasil analisis : ada korelasi yang signifikan antara keikutsertaan kelas ibu hamil dengan kecemasan primigravida dalam menghadapi persalinan, dengan $\mathrm{p}=0,010$ dengan nilai koefisien korelasi Spearman sebesar -0,461 artinya ada korelasi yang kuat antara keikutsertaan kelas ibu hamil dengan kecemasan primigravida. Jika variabel keikutsertaan kelas ibu hamil meningkat maka variabel kecemasan primigravida menurun dan sebaliknya jika variabel keikutsertaan kelas ibu hamil menurun maka variabel kecemasan primigravida akan meningkat. Diharapkan ibu hamil dapat megikuti kelas ibu hamil secara rutin minimal tiga kali.
\end{abstract}

Kata kunci: kelas ibu hamil, kecemasan ibu hamil

\section{Pendahuluan}

Upaya Pemerintah untuk mempercepat penurunan kematian ibu dan bayi melalui peningkatan pengetahuan dan perubahan perilaku ibu dan keluarga. Dengan peningkatan pengetahuan dan perubahan perilaku ini diharapkan kesadaran terhadap pentingnya kesehatan selama kehamilan menjadi meningkat. Program yang diselenggarakan oleh Kementerian Kesehatan untuk mendukung langkah tersebut adalah Kelas Ibu Hamil Kegiatan kelas ibu hamil menggunakan metode pembelajaran salah satunya dengan pembahasan materi Buku KIA. Penggunaan Buku KIA diharapkan dapat meningkatkan kualitas pelayanan Kesehatan Ibu dan Anak serta gizi sehingga salah satu tujuan pembangunan nasional yaitu penurunan AKI dan AKB dapat tercapai. ${ }^{[1]}$

Perilaku merupakan respons atau reaksi seseorang terhadap stimulus (rangsangan dari luar). Hasil penelitian yang dilaksanakan oleh Japan International Cooperation Agency (JICA) bekerjasama dengan Departemen Kesehatan Republik Indonesia pada tahun 2008 di daerah Nusa Tenggara Barat menemukan terdapat peningkatan pengetahuan sikap dan perilaku positif dalam menghadapi kehamilan, persalinan dan masa nifas pada ibu hamil yang mengikuti Kelas Ibu Hamil. ${ }^{(1)}$ Faktor yang mempengaruhi perilaku kesehatan (keikutsertaan ibu hamil untuk mengikuti kelas ibu hamil) antara lain adalah faktor karakteristik ibu yaitu umur, pendidikan, pekerjaan, paritas, faktor predisposisi meliputi pengetahuan, sikap, minat, sosial budaya (adat istiadat), faktor pendukung meliputi sarana pelayanan kesehatan, faktor pendorong meliputi dukungan keluarga, motivasi, petugas kesehatan dan sosial ekonomi. $^{[2]}$

Kelas Ibu hamil merupakan sarana untuk belajar tentang kesehatan bagi ibu hamil, dalam bentuk tatap muka dalam kelompok 
yang bertujuan untuk meningkatkan pengetahuan dan keterampilan ibu-ibu mengenai kehamilan, perawatan kehamilan, persalinan, perawatan nifas, perawatan bayi baru lahir, mitos, penyakit menular dan akte kelahiran. Kelas Ibu Hamil adalah kelompok belajar ibu-ibu hamil dengan umur kehamilan antara 4 minggu sampai dengan 36 minggu (menjelang persalinan) dengan jumlah peserta maksimal 10 orang. ${ }^{[1]}$

Beberapa studi yang telah dilakukan sebelumnya menunjukkan bahwa pelaksanaan kelas ibu hamil belum berjalan dengan baik. Hasil penelitian di Kota Malang menunjukkan baru 30 persen kelas ibu hamil yang sudah dilaksanakan dengan baik, 20 persen belum baik dan 50 persen sudah tidak menyelenggarakan kelas ibu hamil. Hasil penelitian menunjukkan bahwa penyelenggara atau pelaksanan kegiatan Kelas Ibu Hamil (KIH) menyatakan standar dan tujuan KIH belum jelas (32\%), sumberdaya belum memadai bagi (36\%), komunikasi antar organisasi belum berjalan baik $(60 \%)$, karakteristik badan pelaksana belum baik (72\%) dan disposisi belum baik (32\%). Terdapat hubungan bersama-sama antara disposisi/sikap implementor serta standar dan tujuan kebijakan dengan implementasi program kelas ibu hamil ${ }^{(3)}$. Studi lainnya yang dilakukan Kabupaten Jombang mencatat bahwa selama tahun 2010 hingga 2011 terdapat penurunan kehadiran ibu hamil di kelas ibu hamil. ${ }^{[4]}$

Setiap ibu hamil memiliki intensitas rasa cemas yang berbeda-beda. Kecemasan (Ansietas) adalah perasaan takut yang tidak jelas dan tidak didukung oleh situasi. Kehamilan dapat merupakan sumber stressor kecemasan, terutama pada seorang ibu yang labil jiwanya ${ }^{[5]}$. Kecemasan dalam kehamilan muncul pada trimester pertama (0-12 minggu), karena pada trimester ini ibu akan mengalami kelemahan, keletihan, merasa mual dan membuat calon ibu merasa tidak sehat dan semuanya mengalami depresi. Kecemasan terjadi sebagai akibat dari ancaman terhadap harga diri atau identitas diri yang sangat mendasar bagi keberadaan individu. ${ }^{[6]}$

Ibu sudah mengalami kegelisahan dan kecemasan saat awal kehamilan. Kegelisahan dan kecemasan selama kehamilan merupakan kejadian yang tidak terelakkan dan hampir selalu menyertai saat kehamilan. Hal ini merupakan bagian dari suatu proses penyesuaian yang wajar terhadap perubahan fisik dan psikologis yang terjadi saat kehamilan. Perubahan ini diakibatkan karena perubahan hormon yang akan mempermudah janin untuk tumbuh dan berkembang saat dilahirkan. ${ }^{[7]}$

Kecemasan pada ibu hamil trimester III dibagi kedalam kategori jenis kehamilan graviditas, usia, dan tingkat pendidikan ${ }^{[8]}$. Dari 51 responden yang diteliti diperoleh $49 \%$ tidak mengalami kecemasan (normal), $47.1 \%$ kecemasan ringan, 3.9\% kecemasan sedang, dan tidak ada yang mengalami kecemasan berat. Sedangkan menurut penelitan Qurniasih Nila (2014), mengenai aktivitas kelas ibu hamil terhadap kesiapan ibu dalam menghadapi persalinan terhadap 40 responden, responden yang mengikuti kelas ibu hamil, terdapat 28 orang $(70 \%)$ memiliki kesiapan dalam menghadapi persalinan. Sedangkan sisanya 12 responden, tidak memiliki kesiapan menghadapi persalinan (30\%). Dari 12 orang yang tidak siap menghadapi persalinan, 5 diantaranya tidak aktif mengikuti kelas ibu, 6 diantaranya kurang aktif dan 1 diantaranya aktif mengikuti kelas ibu. Hasil penelitian terkait dengan keikursertaan kelas ibu hamil dengan kecemasan ibu hamil menunjukan ada hubungan keikutsertaan ibu hamil dalam kelas hamil dengan tingkat kecemasan dalam menghadapi persalinan pada ibu hamil Tm III ${ }^{[9]}$. Didukung hasil penelitian konseling kelompok pra-persalinan efektif untuk menurunkan kecemasan primigravida dalam menghadapi persalinan ${ }^{[10]}$. Ada pengaruh kelas ibu terhadap penurunan tingkat kecemasan primigravida menghadapi persalinan. ${ }^{[1]}$

Berdasarkan uraian diatas, maka peneliti ingin meneliti atau mengkaji tentang Hubungan Perilaku Keikutsertaan Kelas Ibu Hamil dengan Tingkat Kecemasan Primigravida TM III dalam Menghadapi Persalinan di Desa kalisapu kecamatan slawi.

\section{Metode Penelitian}


Penelitian ini merupakan penelitian kuantitatif. Penelitian ini menggunakan jenis penelitian korelasional. Penelitian korelasional adalah suatu penelitian untuk mengetahui hubungan dan tingkat hubungan antara dua variabel atau lebih tanpa ada upaya untuk mempengaruhi variabel tersebut sehingga tidak terdapat manipulasi variabel. $^{[12]}$

Desain korelasional dipilih karena peneliti akan menentukan hubungan antara perilaku keikutsertaan kelas ibu hamil terhadap tingkat kecemasan dalam menghadapi persalinan pada ibu hamil primigravida TM III. Pendekatan yang dilakukan pada penelitian ini adalah cross sectional karena variabel independen dan variabel dependen diukur dalam waktu yang bersamaan atau simultan. ${ }^{[2]}$

Dalam penelitian ini populasi yang diteliti adalah seluruh ibu hamil TM III di Desa Kalisapu Kecamatan Slawi Maret April sebanyak 30 ibu hamil. sampel yang digunakan adalah keseluruhan populasi, yaitu seluruh ibu hamil di Desa Kalisapu Kecamatan Slawi Kabupaten Tegal Tahun 2016 sebanyak 30 orang.

Penelitian dilakukan di Desa Kalisapu Kecamatan Slawi Kabupaten Tegal dan waktu penelitian Bulan Maret- April 2016. Data primer diperoleh melalui kuesioner yaitu sejumlah pertanyaan tertulis yang digunakan untuk memperoleh informasi dari responden (terlampir).

Pengolahan data dilakukan SPSS versi 16. Uji statistik Spearman Rank dengan $\alpha=$ 0,05

\section{Hasil dan Pembahasan}

Tabel 1. Distribusi Frekuensi Responden berdasarkan Keikutsertaan Kelas Ibu Hamil

\begin{tabular}{lll}
\hline Keikutsertaan Kelas ibu hamil & f & $\%$ \\
\hline Tidak ikut & 13 & 43.3 \\
Ikut & 17 & 56.7 \\
\hline Total & 30 & 100 \\
\hline
\end{tabular}

Berdasarkan tabel diatas diketahui sebagian besar ibu hamil yaitu 53.7\%(17 responden) telah mengikuti kelas ibu hamil

Tabel 2. Distribusi Frekuensi Responden berdasarkan tingkat kecemasan Ibu Hamil.

\begin{tabular}{lll}
\hline $\begin{array}{l}\text { Tingkat } \\
\text { kecemasan }\end{array}$ & F & $\mathbf{\%}$ \\
cemas ringan & 19 & 63.3 \\
cemas sedang & 10 & 33.3 \\
cemas berat & 1 & 3.3 \\
Total & 30 & 100.0 \\
\hline \multicolumn{2}{c}{ Tingkat kecemasan ibu hamil dalam } \\
menghadapi persalinan didominasi dalam \\
kecemasan tingkat ringan yaitu sebesar 63.3 \\
\% (19 responden)
\end{tabular}

Tabel 3. Hubungan Tingkat Kecemasan dengan Keikutsertaan Kelas Ibu Hamil

\begin{tabular}{|c|c|c|c|c|}
\hline \multirow{2}{*}{$\begin{array}{c}\text { Keikutsertaan } \\
\text { Kelas ibu } \\
\text { hamil }\end{array}$} & \multicolumn{3}{|c|}{ Kecemasan } & \multirow{2}{*}{$\begin{array}{c}P \\
\text { Value }\end{array}$} \\
\hline & Ringan & Sedang & Berat & \\
\hline Tidak ikut & $\begin{array}{l}5 \\
(38.5 \%)\end{array}$ & $\begin{array}{l}7 \\
(53.8 \%)\end{array}$ & $\begin{array}{l}1 \\
(7.7 \%)\end{array}$ & \\
\hline Ikut & $\begin{array}{l}14 \\
(82.4 \%)\end{array}$ & $\begin{array}{l}3 \\
(17.6 \%)\end{array}$ & 0 & 0.01 \\
\hline Total & $\begin{array}{l}19 \\
(63.3 \%)\end{array}$ & $\begin{array}{l}10 \\
(33.3 \%)\end{array}$ & $\begin{array}{l}1 \\
(3.3 \%)\end{array}$ & \\
\hline \multicolumn{5}{|c|}{$\begin{array}{l}\text { diketahui bahwa responden tidak ikut kelas } \\
\text { ibu hamil yang mengalami tingkat } \\
\text { kecemasan ringan sebanyak } 5 \text { responden } \\
(38,5 \%) \text {, kecemasan sedang sebanyak } 7 \\
\text { responden }(53,8 \%) \text { dan yang kecemasanya } \\
\text { berat sebanyak } 1 \text { orang }(7,7 \%) \text {. Responden } \\
\text { yang mengikuti kelas ibu hamil mayoritas } \\
\text { mengalami tingkat kecemasan ringan } \\
\text { sebanyak } 14 \text { responden }(82,4 \%) \text { dan } \\
\text { kecemasan sedang sebanyak } 3 \text { responden } \\
(176 \%)\end{array}$} \\
\hline \multicolumn{5}{|c|}{$\begin{array}{l}\text { Hasil analisis korelasi Spearman } \\
\text { diperoleh hasil ada korelasi yang signifikan } \\
\text { antara keikutsertaan kelas ibu hamil dengan } \\
\text { kecemasan primigravida dalam menghadapi } \\
\text { persalinan, dengan } p=0,010 \text { dengan nilai } \\
\text { koefisien korelasi Spearman sebesar }-0,461 \\
\text { artinya ada korelasi yang kuat antara } \\
\text { keikutsertaan kelas ibu hamil dengan } \\
\text { kecemasan primigravida, jika variabel } \\
\text { keikutsertaan senam hamil meningkat maka } \\
\text { variabel kecemasan primigravida menurun } \\
\text { dan kecemasan primigravida menurun dan } \\
\text { sebaliknya jika variabel keikutsertan senam }\end{array}$} \\
\hline
\end{tabular}


hamil menurun maka variabel kecemasan primigravida meningkat.

Dari hasil penelitian diperoleh responden yang mengikuti kelas ibu hamil sebagian besar responden mengalami kecemasan ringan dalam menghadapi persalinan sedangkan responden yang tidak pernah mengikuti senam hamil selama kehamilan trimester ketiga mengalami cemas sedang dan cemas ringan. Semakin sering ibu hamil melakukan senam hamil semakin berkurang tingkat kecemasannya dalam menghadapi persalinan dan sebaliknya jika tidak pernah melakukan senam hamil maka kecemasan ibu hamil akan meningkat. Pada latihan senam hamil terdapat teknik relaksasi yang dapat mengurangi kecemasan, saat individu mengalami ketegangan dan kecemasan yang bekerja adalah sistem saraf simpatetis, sedangkan saat rileks yang bekerja adalah sistem saraf para simpatetis. Jika sistem saraf simpatetis meningkatkan rangsangan atau memacu organ tubuh, memacu meningkatnya denyut jantung dan pernafasan, serta menimbulkan penyempitan pembuluh darah tepi (peripheral) dan pembesaran pembuluh darah pusat, maka sebaliknya sistem saraf parasimpatetis menstimulasi turunnya semua fungsi yang dinaikkan oleh sistem saraf simpatetis dan menaikkan semua fungsi yang diturunkan oleh sistem saraf simpatetis. Maka relaksasi dapat menekan rasa tegang dan cemas. Data yang diperoleh dari hasil penelitian menunjukkan jumlah responden yang jarang mengikuti senam hamil lebih banyak, dari hasil wawancara peneliti kepada responden hal ini disebabkan karena pendidikan dan status pekerjaan responden. Hasil penelitian menunjukkan tingkat pendidikan responden yang mengikuti senam hamil lebih tinggi dari responden yang tidak mengikuti senam hamil. Sesuai dengan teori bahwa pendidikan yang tinggi memungkinkan untuk memiliki pengetahuan yang tinggi dan cenderung untuk mendapatkan informasi yang lebih mudah tentang kesehatan terutama tentang senam hamil serta manfaatnya sehingga ibu hamil lebih cepat termotivasi untuk mengikuti senam hamil. Pengetahuan dan informasi tentang senam hamil terkadang tidak diperoleh melalui pendidikan formal, tetapi juga melalui keluarga, teman dan masyarakat.

Berdasarkan perhitungan Spearman's rho dengan $\alpha=0,05$ diperoleh nilai $\mathrm{p}$ sebesar 0,010 Karena nilai $p<\alpha$ berarti secara statistik hasil pengujian signifikan, atau menolak Ho, maka dapat disimpulkan bahwa ada hubungan perilaku keikutsertaan kelas ibu hamil dengan tingkat kecemasan dalam menghadapi persalinan pada ibu hamil primigravida tm iii di desa kalisapu. Hal ini menggambarkan bahwa ibu hamil yang mengikuti kelas ibu hamil dalam menghadapi persalinan tingklat kecemasamnnya ringan.

Beberapa hasil penelitian terkait dengan keikursertaan klas ibu hamil dengan kecemasan ibu hamil menunjukan Ada hubungan keikutsertaan ibu hamil dalam kelas hamil dengan tingkat kecemasan dalam menghadapi persalinan pada ibu hamil Tm III ${ }^{[9]}$

Didukung hasil penelitian konseling kelompok pra-persalinan efektif untuk menurunkan kecemasan primigravida dalam menghadapi persalinan ${ }^{[10]}$. Ada pengaruh kelas ibu terhadap penurunan tingkat kecemasan primigravida menghadapi persalinan ${ }^{[11]}$.

Hasil penelitian yang lain menunjukkan bahwa ada hubungan keikutsertaan ibu hamil dalam kelas hamil dengan tingkat kecemasan dalam menghadapi persalinan pada ibu hamil TM III.

\section{Kesimpulan}


Berdasarkan hasil penelitian dan pembahasan dapat disimpulkan bahwa keikutsertaan kelas ibu hamil primigravida sebanyak 17 responden $(56,7 \%)$ dan yang tidak ikut kelas ibu hamil sebanyak 13 responden (43,3\%). Responden yang mengikuti kelas ibu hamil mayoritas mengalami kecemasan ringan dan responden yang tidak pernah mengikuti kelas ibu hamil mengalami cemas ringan dan cemas sedang. Ada korelasi yang kuat antara kelas ibu hamil dengan kecemasan primigravida trimester ketiga dalam menghadapi persalinan di Puskesmas Slawi, dengan keikutsertaan kelas ibu hamil yang meningkat akan menurunkan kecemasan primigravida atau dengan keikutsertaan kelas ibu hamil yang menurun maka kecemasan primigravida meningkat.

\section{Daftar Pusta ka}

[1] Departemen Kesehatan Republik Indonesia. 2009. Pedoman Pelaksanaan Kelas Ibu Hamil. Jakarta: Departemen Kesehatan RI.

[2] Notoatmodjo. 2012. Metodologi Penelitian Kesehatan. Jakarta : Rineka Cipta.

[3] Jiarti, Kusbandiyah. 2013. Analisis Implementasi Program KIH oleh Bidan Puskesmas di Kota Malang. Semarang: Program Pascasarjana Magister Ilmu Kesehatan Masyarakat Universitas Diponegoro (Tesis).

[4] Rizky, L.D. 2012. Persepsi Ibu Hamil tentang Kelas Ibu Hamil di Desa Sidomulyo Wilayah Kerja Puskesmas megaluh Kabupaten Jombang. Jakarta: Jurusan Keperawatan Poltekkes Jakarta (KTI).

[5] Viebeck, S. 2012. Buku Ajar Keperawatan Jiwa. Jakarta : EGC.

[6] Kusmiati, Y. 2009. Perawatan Ibu Hamil. Jakarta: Fitramaya.

[7] Kushartanti, dkk. 2010. Senam Hamil: Menyamankan Kehamilan,
Mempermudah

Persalinan.

Yogyakarta: Lintang Pustaka.

[8] Yuliana, S. 2008. Gambaran Tingkat Kecemasan Ibu Hamil Trimester III di UPT Ibrahim Adjie Kota Bandung. Bandung : Fakultas Ilmu Keperawatan Universitas Padjajaran (Skripsi)

[9] Hasuki, I. 2010. Buku Saku Perawatan Kesehatan Ibu dan Anak. Jakarta : EGC.

[10] Janiwarty dan Pieter. 2013. Pendidikan Psikologi Untuk Bidan. Yogyakarta: Rapha Publishing.

[11] Rohyadi. 2014. Kamus Praktis Kebidanan. Surabaya: Kashiko Publisher.

[12] Hawari, S. 2008. Manajemen Stres Cemas dan Depresi. Jakarta : Balai Penerbit FKUI. 
